\title{
Bismuth oxide aqueous colloidal nanoparticles inhibit Candida albicans growth and biofilm formation
}

This article was published in the following Dove Press journal:

International Journal of Nanomedicine

23 April 2013

Number of times this article has been viewed

\author{
Rene Hernandez-Delgadillo' \\ Donaji Velasco-Arias ${ }^{3}$ \\ Juan Jose Martinez-Sanmiguel ${ }^{2}$ \\ David Diaz ${ }^{3}$ \\ Inti Zumeta-Dube ${ }^{3}$ \\ Katiushka Arevalo-Niño' \\ Claudio Cabral-Romero ${ }^{2}$ \\ 'Facultad de Ciencias Biológicas, \\ Instituto de Biotecnologia, \\ Universidad Autonoma de Nuevo \\ Leon, UANL, Monterrey, Mexico; \\ ${ }^{2}$ Facultad de Odontología, Universidad \\ Autonoma de Nuevo Leon, UANL, \\ Monterrey, México; ${ }^{3}$ Facultad de \\ Quimica, Universidad Nacional \\ Autonoma de Mexico, UNAM, \\ Distrito Federal, México
}

Correspondence: Claudio Cabral-

Romero

Universidad Autonoma de Nuevo Leon,

UANL, Facultad de Odontologia,

Dr E Aguirre Pequeño and Silao s/n

Mitras centro, Monterrey,

Nuevo Leon CP 64460, Mexico

Tel +52 81832940000 ext 3I53

Email claudiohubble@hotmail.com

David Diaz

Universidad Nacional Autonoma de Mexico, Facultad de Química, Avenida Universidad 3000, Ciudad Universitaria, Coyoacan, Mexico City CP 045 I0,

Mexico

Tel +5255 56223813

Email david@unam.mx

\begin{abstract}
Multiresistance among microorganisms to common antimicrobials has become one of the most significant concerns in modern medicine. Nanomaterials are a new alternative to successfully treat the multiresistant microorganisms. Nanostructured materials are used in many fields, including biological sciences and medicine. Recently, it was demonstrated that the bactericidal activity of zero-valent bismuth colloidal nanoparticles inhibited the growth of Streptococcus mutans; however the antimycotic potential of bismuth nanostructured derivatives has not yet been studied. The main objective of this investigation was to analyze the fungicidal activity of bismuth oxide nanoparticles against Candida albicans, and their antibiofilm capabilities. Our results showed that aqueous colloidal bismuth oxide nanoparticles displayed antimicrobial activity against $C$. albicans growth (reducing colony size by $85 \%$ ) and a complete inhibition of biofilm formation. These results are better than those obtained with chlorhexidine, nystatin, and terbinafine, the most effective oral antiseptic and commercial antifungal agents. In this work, we also compared the antimycotic activities of bulk bismuth oxide and bismuth nitrate, the precursor metallic salt. These results suggest that bismuth oxide colloidal nanoparticles could be a very interesting candidate as a fungicidal agent to be incorporated into an oral antiseptic. Additionally, we determined the minimum inhibitory concentration for the synthesized aqueous colloidal $\mathrm{Bi}_{2} \mathrm{O}_{3}$ nanoparticles.
\end{abstract}

Keywords: antimycotic agent, antifungal, cytotoxicity

\section{Introduction}

The occurrence of microorganisms living in cooperative, aggregated communities is called a biofilm. Biofilms can form on many kinds of surfaces and interfaces, including the human body. ${ }^{1}$ The most common biofilms associated with human disease episodes are the fungi of the genus Candida, most notably Candida albicans, which causes both superficial and systemic disease. C. albicans biofilm is commonly found in children and elderly persons with a deficient immune system, and it is the etiological agent of oral moniliasis; the mortality of patients with invasive candidiasis can be as high as $40 \% .^{2,3}$ Fungal infections are difficult to eradicate, requiring high quantities and longtime exposure to an antimycotic agent to efficiently eliminate the etiological pathogen. ${ }^{4}$

Multiresistance among pathogen microorganisms has become one of the most important problems in current medicine. ${ }^{5}$ Since early reports in 1980, new evidence has suggested the emergence of multiresistant strains of Candida, suggesting that multiresistance is not an exclusive phenomenon of bacteria. ${ }^{6,7}$ The absence of new alternatives to efficiently treat these multiresistant microorganisms is a real problem, 
and it is urgent to synthesize new broad spectrum drugs to fight antimicrobial resistance.

Typically, bismuth is found as bismuthinite (bismuth sulfide), bismite (bismuth oxide $\left[\mathrm{Bi}_{2} \mathrm{O}_{3}\right]$ ), and bismuthite (bismuth carbonate). ${ }^{8}$ In medicine, bismuth, in the form of bismuth subsalicylate, has been employed as an antidiarrheal to treat nauseas, vomiting, and stomach pain. ${ }^{9}$

The chemistry of the binary oxides of bismuth is dominated by the +3 oxidation state. Most of the work on bismuth, concentrates on $\mathrm{Bi}_{2} \mathrm{O}_{3} \cdot \mathrm{Bi}_{2} \mathrm{O}_{3}$ shows a distinctive polymorphism, including the following solid state phases: $\alpha-\mathrm{Bi}_{2} \mathrm{O}_{3}, \beta-\mathrm{Bi}_{2} \mathrm{O}_{3}, \gamma-\mathrm{Bi}_{2} \mathrm{O}_{3}, \delta-\mathrm{Bi}_{2} \mathrm{O}_{3}$, and the recently characterized $\varepsilon-\mathrm{Bi}_{2} \mathrm{O}_{3} \cdot{ }^{10}$ The $\alpha-\mathrm{Bi}_{2} \mathrm{O}_{3}$ is the most thermodynamically stable phase at room temperature and pressure. So, under standard reaction conditions in aqueous solutions, the $\alpha-\mathrm{Bi}_{2} \mathrm{O}_{3}$ is formed, a poorly water-soluble specie that carries surface hydroxyl groups. ${ }^{11} \alpha-\mathrm{Bi}_{2} \mathrm{O}_{3}$ is a basic oxide and its $\mathrm{Bi}-\mathrm{O}$ bonds are predominantly ionic, ${ }^{12}$ it is a p-type semiconductor material. ${ }^{10}$

$\mathrm{Bi}_{2} \mathrm{O}_{3}$ is a derivative of great technological importance, and it is used in the manufacture of glass and ceramic products, and also, as catalyst in the oxidation of hydrocarbons. It is widely used in applications, such as microelectronics, and sensor and optical technology. ${ }^{13,14}$

Nanoparticles (NPs) have large surface areas, and therefore, they have increased interactions with biological targets. We recently demonstrated the antibacterial effectiveness of zero-valent bismuth NPs at inhibiting the growth of Streptococcus mutans $;{ }^{15}$ however; at the present time the antimycotic potential of bismuth nanostructured derivatives are not known. In this report, we present evidence of the antimycotic properties of $\mathrm{Bi}_{2} \mathrm{O}_{3} \mathrm{NPs}$ against the growth of $C$. albicans and its capability to eliminate the fungal biofilm - the biocidal activity of $\mathrm{Bi}_{2} \mathrm{O}_{3} \mathrm{NPs}$ was very similar to that obtained with chlorhexidine, a commonly used oral antiseptic and commercial antifungals as nystatin and terbinafine. Additionally, the $C$. albicans antifungal capacities of bulk $\mathrm{Bi}_{2} \mathrm{O}_{3}$ material and bismuth nitrate, the precursor salt used in the $\mathrm{Bi}_{2} \mathrm{O}_{3}$ colloidal NPs synthesis, are compared.

\section{Materials and methods Synthesis of $\mathrm{Bi}_{2} \mathrm{O}_{3} \mathrm{NP}$}

For the synthesis of $\mathrm{Bi}_{2} \mathrm{O}_{3}$ nanoclusters $\left(\mathrm{Bi}_{2} \mathrm{O}_{3} \mathrm{NCs}\right)$, the following chemical reagents were used: bismuth nitrate pentahydrate $\left(\mathrm{Bi}\left(\mathrm{NO}_{3}\right)_{3} \cdot 5 \mathrm{H}_{2} \mathrm{O}\right), 98 \%$ (Sigma-Aldrich, St Louis, MO, USA); $\mathrm{Bi}_{2} \mathrm{O}_{3}, 99.999 \%$ trace metals basis (Sigma-Aldrich); potassium hydroxide (KOH), 85\% (Meyer,
Tlahuac, Mexico City, Mexico); argon(Ar), 99.998\% (Praxair Inc, Danbury, CT, USA); and deionized water, $18.2 \Omega$ (Milli $\mathrm{Q}^{\circledR}$; Thermo Fisher Scientific, Waltham, MA, USA). These chemical substances were used as they were received.

We used a typical preparation method for the production of the $\mathrm{Bi}_{2} \mathrm{O}_{3} \mathrm{NP}$ colloids, as follows: First, all water to be used in the synthesis was boiled and after cooling to room temperature, was bubbled with argon gas for 15 minutes in order to prevent carbonation. Subsequently, $0.0274 \mathrm{~g}$ of $\mathrm{Bi}\left(\mathrm{NO}_{3}\right)_{3} \cdot 5 \mathrm{H}_{2} \mathrm{O}$ were dissolved in $24.5 \mathrm{~mL}$ of the prepared water. This solution was heated, under vigorous magnetic stirring, at $80^{\circ} \mathrm{C}$. Then, $0.5 \mathrm{~mL}$ of an aqueous solution of $\mathrm{KOH} 0.032 \mathrm{M}$ were added to the $\mathrm{Bi}\left(\mathrm{NO}_{3}\right)_{3} \cdot 5 \mathrm{H}_{2} \mathrm{O}$ solution. The final concentrations of bismuth and hydroxide ions were $2 \times 10^{-3} \mathrm{M}$ and $6 \times 10^{-3} \mathrm{M}$, respectively. It is worth noting that during the entire process of dissolution and mixing of the reagents, a weak stream of argon was blowing over the surface of the reaction mixture. The newly synthesized yellowish $\mathrm{Bi}_{2} \mathrm{O}_{3}$ powder NPs were isolated by centrifugation at $14,000 \mathrm{rpm}$, for 30 minutes. Afterwards, they were washed with previously decarbonated water, three times. Finally, the powdered $\mathrm{Bi}_{2} \mathrm{O}_{3} \mathrm{NPs}$ were once again resuspended in water and stored at room temperature for approximately 30 minutes, until their use. In order to prove the reproducibility of this synthesis method, these colloids were prepared in triplicate.

\section{Characterization of $\mathrm{Bi}_{2} \mathrm{O}_{3} \mathrm{NPs}$}

The needle-shaped morphology of $\mathrm{Bi}_{2} \mathrm{O}_{3}$ NPs was determined by transmission electron (TEM) micrographs obtained using a JEOL 1200-EXII (JEOL Ltd, Tokyo, Japan) of 40-120 KV. Single drops of the ethanol nanoparticle suspension were deposited onto 200 mesh copper grids coated with a carbon/ collodion layer.

The $\mathrm{Bi}_{2} \mathrm{O}_{3}$ monoclinic phase identification was obtained from the X-ray diffraction pattern (PDF 41-1449 card), recorded on a Bruker D2-Phaser diffractometer (Bruker Corp, Billerica, MA, USA), using $\mathrm{Cu} \mathrm{K} \alpha$ radiation, $1.5406 \AA$ (30 kV, $10 \mathrm{~mA})$. The crystallite size, $77 \mathrm{~nm}$, was determined using the Scherrer equation. From the X-ray diffraction pattern and the TEM images, we observed needle-shaped crystallites, which indicated a textured material (in the 120 direction) (Figure 1).

\section{Antimycotic activity of $\mathrm{Bi}_{2} \mathrm{O}_{3} \mathrm{NPs}$ against $C$. albicans growth}

C. albicans (No 90029) was obtained from the American Type Culture Collection, (Manassas, VA, USA). The antifungal effect of $\mathrm{Bi}_{2} \mathrm{O}_{3}$ NPs on $C$. albicans growth was determined using a 3-(4,5-dimethylthiazol-2-yl)-2,5-diphenyltetrazolium bromide (MTT) assay (Biotium Inc, Hayward, CA, USA), ${ }^{16,17}$ following 


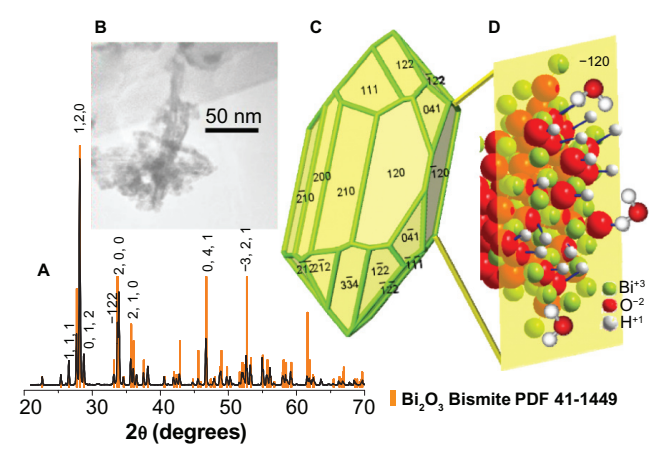

Figure I Structural and morphological characterization of $\mathrm{Bi}_{2} \mathrm{O}_{3} \mathrm{NPs}$, the crystalline habit, and the idealization of the hydroxyl ions and water molecules interactions with the -120 surface plane.

Notes: (A) $\mathrm{Bi}_{2} \mathrm{O}_{3} \mathrm{NPs}$ X-ray diffraction pattern. This sample was synthesized in water, as described in the Materials and methods section. In this case, the observed peaks match with the $\alpha$-phase (monoclinic) of $\mathrm{Bi}_{2} \mathrm{O}_{3}$. (B) TEM image of the $\mathrm{Bi}_{2} \mathrm{O}_{3}$ NPs clearly shows the needle shape exhibited by these nanoclusters. (C) This model shows the crystal structure of a representative particle, with the respective exposed planes. (D) The images shows a $(-120)$ plane sketch, in particular, the enhanced interaction of bismuth atoms with hydroxyl ions and water molecules.

Abbreviations: $\mathrm{Bi}_{2} \mathrm{O}_{3}$, bismuth oxide; NP, nanoparticle; TEM, transmission electron microscope.

the instructions of the manufacturer. C. albicans was grown in Trypticase ${ }^{\mathrm{TM}}$ Soy Broth (TSB) (BD Biosciences, Franklin Lakes, $\mathrm{NJ}, \mathrm{USA}$ ) at $37^{\circ} \mathrm{C}$, overnight in aerobic conditions. The fungal cells were counted, using a Neubauer chamber, and $1 \times 10^{4}$ cells were inoculated in $100 \mu \mathrm{L}$ of TSB medium, in a 96-well polystyrene plate. Three wells with only TSB medium were used as controls for growth of $C$. albicans. Chlorhexidine 2\% (Ultradent Products Inc, South Jordan, UT, USA) was used as a positive antimicrobial control; additionally, terbinafine $1 \%$ (Novartis Pharmaceuticals Corp, Basel, Switzerland) and commercial $\mathrm{Bi}_{2} \mathrm{O}_{3}$ were used as antifungal positive controls.

Hereinafter, the concentrations given refer to the initial concentration of the respective bismuth precursor. We used $50 \mu \mathrm{L}$ of a $2 \mathrm{mM}$ of $\mathrm{Bi}_{2} \mathrm{O}_{3} \mathrm{NP}$ dispersion, in a total volume of $150 \mu \mathrm{L}$, to interfere with bacterial growth. As additional controls, $2 \mathrm{mM}$ of $\mathrm{Bi}_{2} \mathrm{O}_{3}$ (bulk material) aqueous suspension and $2 \mathrm{mM}$ of $\mathrm{Bi}\left(\mathrm{NO}_{3}\right)_{3} \cdot 5 \mathrm{H}_{2} \mathrm{O}$ aqueous solution (the precursor bismuth salt), were added separately to cells, to compare the antifungal activities of the metallic salt, bulk material, and nanostructured samples. In this research, we avoided the use of organic solvents in order to prevent possible interference with the antifungal and cytotoxic properties of the $\mathrm{Bi}_{2} \mathrm{O}_{3}$ NPs.

The 96-well plate was incubated at $37^{\circ} \mathrm{C}$ overnight. Next, $10 \mu \mathrm{L}$ of MTT was added to each well, and the plate was protected against light and incubated at $37^{\circ} \mathrm{C}$ for 2 hours. Next, $200 \mu \mathrm{L}$ of dimethyl sulfoxide was added to dissolve the reduced MTT species. The amount of live cells was determined using a microplate absorbance reader (iMark ${ }^{\mathrm{TM}}$; Bio-Rad Laboratories, Philadelphia, PA, USA), at $595 \mathrm{~nm}$.
The experiments were repeated three times, and the measured optical density was analyzed by descriptive statistics.

\section{Determination of minimal inhibitory concentration (MIC) of $\mathrm{Bi}_{2} \mathrm{O}_{3} \mathrm{NPs}$}

The MIC was determined as described in a previous work. ${ }^{18}$ Briefly, a 5 tube in the McFarland scale, with $1 \times 10^{9} \mathrm{CFU}$, was obtained (McFarland scale are fungal solutions. There are 1-9 ranges in this scale with a specific number of microbes in each one): C. albicans was grown in TSB agar and incubated at $37^{\circ} \mathrm{C}$ for 24 hours. One colony was inoculated in $5 \mathrm{~mL}$ of TSB medium and incubated at $37^{\circ} \mathrm{C}$ for 24 hours. The fungal count was determined with a Neubauer chamber. Tubes with a final concentration of $1 \times 10^{6} \mathrm{CFU}$ were obtained by dilution of the 5 tube in the McFarland scale. $\mathrm{The}_{2} \mathrm{Bi}_{2}$ NP suspension was diluted to final concentrations of $0.25,0.5,1$, and 1.5 , from the $2 \mathrm{mM}$ stock. Then, $1 \mathrm{~mL}$ of each $\mathrm{Bi}_{2} \mathrm{O}_{3} \mathrm{NP}$ dispersion was mixed with a fungal culture medium and then, incubated at $37^{\circ} \mathrm{C}$ for 18 hours. The MIC was determined by the presence or absence of turbidity in the different tubes containing the NPs.

\section{Biofilm inhibitory activity of $\mathrm{Bi}_{2} \mathrm{O}_{3}$ NPs}

The antibiofilm activity of the $\mathrm{Bi}_{2} \mathrm{O}_{3}$ NPs was determined by fluorescence microscopy, following the methodology described above. To observe the biofilm, SYTO ${ }^{\circledR} 9$ green fluorescent nucleic acid stain (Life Technologies, Carlsbad, CA, USA) was added, to a final concentration of $20 \mu \mathrm{M} .{ }^{19,20}$ The 96-well plate was incubated for 30 minutes at room temperature and protected against light. The $C$. albicans biofilm was visualized with a Carl Zeiss Z1 Axio Inverter microscope (Carl Zeiss Meditec, Jena, Germany), at $485 \mathrm{~nm}$.

\section{Cytotoxicity of $\mathrm{Bi}_{2} \mathrm{O}_{3} \mathrm{NPs}$ on culture cells by fluorescence microscopy}

It is important to emphasize that we did not find any report concerning cytotoxicity of common bismuth nanostructured derivatives. We found one related publication describing the stability, cytotoxicity, and potential use of $\mathrm{KBi}\left(\mathrm{H}_{2} \mathrm{O}\right)_{2}\left[\mathrm{Fe}(\mathrm{CN})_{6}\right] 3 \mathrm{H}_{2} \mathrm{O}$ NPs - of course, this cyano species is extremely toxic. ${ }^{21}$

In this research we used monkey kidney (Vero) cells to analyze the cytotoxic effect of $\mathrm{Bi}_{2} \mathrm{O}_{3} \mathrm{NPs}$. A confluent monolayer of Vero cells (CCL-81; ATTCC) was grown in minimal essential media (MEM) (Life Technologies) supplemented with 10\% of Fetal Bovine Serum (FBS) (Life Technologies), at $37^{\circ} \mathrm{C}$ with $5 \%$ of $\mathrm{CO}_{2}$, in a Nunc ${ }^{\circledR}$ Lab-Tek $^{\circledR}$ Chamber Slide $^{\mathrm{TM}}$ System (16 wells; Thermo Fisher Scientific). This was exposed to $2 \mathrm{mM}$ of $\mathrm{Bi}_{2} \mathrm{O}_{3}$ NPs for 24 hours, and the possible cytotoxic effect was detected by fluorescence microscopy. For the negative control, cells without NPs were employed. The Vero cells were 
washed three times with phosphate-buffered saline (PBS), and 4',6-diamidino-2-phenylindole (DAPI) (Abcam Inc, Cambridge, UK) was added to stain the nucleus of cells. ${ }^{22}$ Cytotoxicity was interpreted as the presence of a degraded or amorphous nucleus, observing at $365 \mathrm{~nm}$ with an inverter Carl Zeiss microscope.

\section{Results}

\section{Synthesis and characterization of $\mathrm{Bi}_{2} \mathrm{O}_{3} \mathrm{NPs}$}

The colloidal dispersions of $\mathrm{Bi}_{2} \mathrm{O}_{3} \mathrm{NPs}$ prepared from $2 \times 10^{-3} \mathrm{M}$ $\mathrm{Bi}\left(\mathrm{NO}_{3}\right)_{3} \cdot 5 \mathrm{H}_{2} \mathrm{O}$ and $6 \times 10^{-3} \mathrm{M}$ of $\mathrm{KOH}$ in deionized water yielded a fine beige powder with an approximate crystallite size of $77 \mathrm{~nm}$. The X-ray diffraction pattern of the $\mathrm{Bi}_{2} \mathrm{O}_{3} \mathrm{NP}$ powder showed the presence of $\alpha$-phase nanocrystallites and the absence of other possible compounds (like carbonated elements) generated during their synthesis (Figure 1). The synthesized $\mathrm{Bi}_{2} \mathrm{O}_{3}$ NPs remained stable at room temperature for 15 days, and no visible trace of carbonation was observed, since the suspended particles in water kept their yellowish color. This established that the antimycotic and antibiofilm properties were associated only with the presence of $\mathrm{Bi}_{2} \mathrm{O}_{3} \mathrm{NPs}$.

\section{Antimycotic activity of $\mathrm{Bi}_{2} \mathrm{O}_{3} \mathrm{NPs}$ against $C$. albicans growth}

To explore the possible antifungal activity of $\mathrm{Bi}_{2} \mathrm{O}_{3}$ NPs, their effect on C. albicans growth was determined. The results showed that $\mathrm{Bi}_{2} \mathrm{O}_{3}$ NPs reduced the number of fungi by $85 \%$, in comparison with the control fungi grown in medium. At the same time, the treatment with $2 \%$ chlorhexidine and $1 \%$ terbinafine (inhibition controls) showed a $44 \%$ and $51 \%$ of reduction in the number of fungi, respectively, when compared with nontreated cells. The antifungal effect of $\mathrm{Bi}_{2} \mathrm{O}_{3} \mathrm{NPs}$ was two times better when compared with the bulk $\mathrm{Bi}_{2} \mathrm{O}_{3}$ material (Figure 2), suggesting that nanostructured $\mathrm{Bi}_{2} \mathrm{O}_{3}$ is more effective as an antifungal agent.

\section{Determination of minimal inhibitory concentration of $\mathrm{Bi}_{2} \mathrm{O}_{3} \mathrm{NPs}$}

In order to characterize the antifungal activity of $\mathrm{Bi}_{2} \mathrm{O}_{3} \mathrm{NPs}$, we determined their MIC. The result obtained was $1.5 \mathrm{mM}$ (Figure 3). This result is important to know as it represents the minimal quantity of $\mathrm{Bi}_{2} \mathrm{O}_{3} \mathrm{NPs}$ that is required to effectively interfere with C. albicans growth.

\section{Biofilm inhibitory activity of $\mathrm{Bi}_{2} \mathrm{O}_{3} \mathrm{NPs}$}

In the previous experiment, we measured the antimycotic activity of $\mathrm{Bi}_{2} \mathrm{O}_{3}$ NPs. In order to analyze the possible biofilm inhibition of $C$. albicans by bismuth nanoclusters,

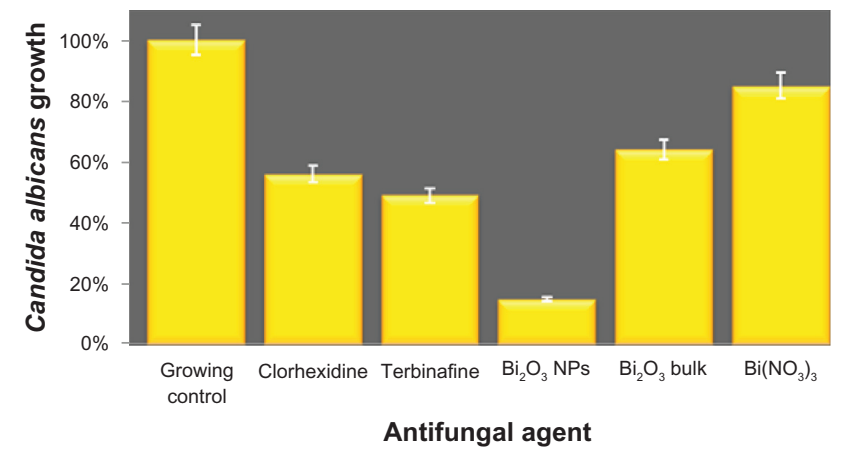

Figure 2 Antifungal activity of bismuth oxide nanoparticles against Candida albicans growth.

Notes: The $y$ axis shows the optical density units of $C$. albicans growth. $C$. albicans culture without inhibitor was used as the growth control, whereas chlorhexidine $2 \%$, terbinafine $1 \%, \mathrm{Bi}_{2} \mathrm{O}_{3}$ (bulk material), and $\mathrm{Bi}\left(\mathrm{NO}_{3}\right)_{3} \cdot 5 \mathrm{H}_{2} \mathrm{O}$ were used as positive inhibition controls. For these experiments, we used a concentration of $2 \mathrm{mM}$ of the respective bismuth species.

Abbreviations: $\mathrm{Bi}_{2} \mathrm{O}_{3}$, bismuth oxide; $\mathrm{Bi}\left(\mathrm{NO}_{3}\right)_{3} \cdot 5 \mathrm{H}_{2} \mathrm{O}$, bismuth nitrate pentahydrate; NP, nanoparticle.

the antibiofilm activity of $\mathrm{Bi}_{2} \mathrm{O}_{3}$ NPs was determined by fluorescence microscopy. The results showed a complete inhibition of biofilm formation by chlorhexidine (Figure 4B), terbinafine (Figure 4C), and $\mathrm{Bi}_{2} \mathrm{O}_{3} \mathrm{NPs}$ (Figure 4D), compared with the control (Figure 4A). The results did not change when $\mathrm{Bi}_{2} \mathrm{O}_{3} \mathrm{NPs}$ were added at different postinoculation times we tested the biofilm inhibitory activity at 6 and 18 hours postinoculation, obtaining similar results (data not shown). These data indicate that $\mathrm{Bi}_{2} \mathrm{O}_{3}$ NPs have an antibiofilm activity that is as effective as chlorhexidine and terbinafine.

\section{Cytotoxicity of $\mathrm{Bi}_{2} \mathrm{O}_{3} \mathrm{NPs}$ in culture cells, by fluorescence microscopy}

The cytotoxic effect of $\mathrm{Bi}_{2} \mathrm{O}_{3}$ NPs was evaluated in monkey kidney (Vero) cells by fluorescence microscopy. The results

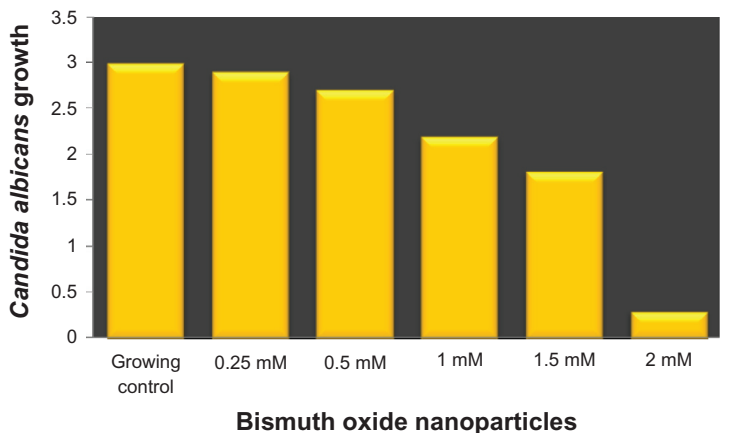

Figure $3 \mathrm{MIC}$ of bismuth oxide nanoparticles against Candida albicans growth. Notes: The $y$ axis shows the optical density units of $C$. albicans growth; the $x$ axis shows the different concentrations of $\mathrm{Bi}_{2} \mathrm{O}$ NPs analyzed. $C$. albicans culture without inhibitor was used as a growth control. Experiments were carried out three times and each time by triplicate. Average results were obtained from the three independent experiments.

Abbreviations: $\mathrm{Bi}_{2} \mathrm{O}_{3}$, bismuth oxide; $\mathrm{MIC}$, minimal inhibitory concentration; NP, nanoparticle. 

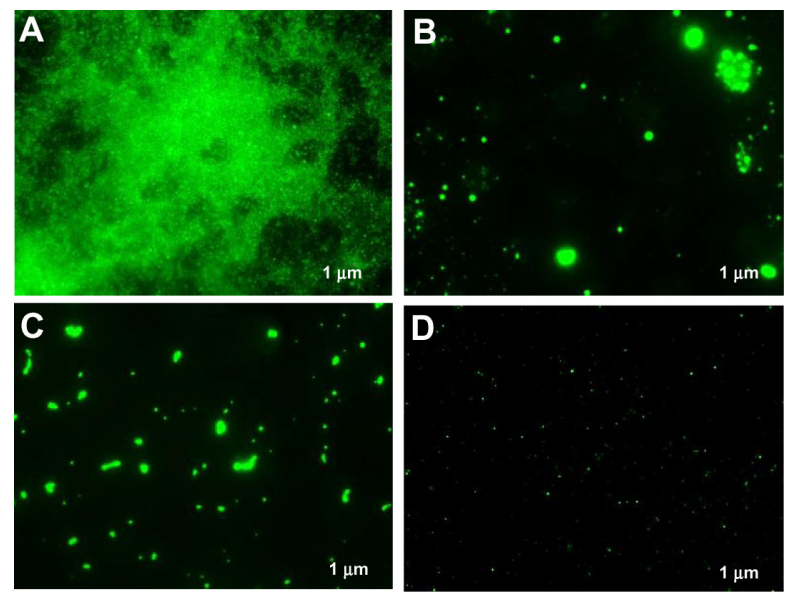

Figure 4 Inhibition of Candida albicans biofilm detected by fluorescence microscopy, after 24 hours. As a growth control, C. albicans was added to culture media; chlorhexidine $2 \%$ and terbinafine $1 \%$ were employed as positive inhibition controls. In these experiments, we used a concentration of $2 \mathrm{mM} \mathrm{Bi}_{2} \mathrm{O}_{3} \mathrm{NPs}$. (A) Growth control; (B) chlorhexidine; (C) terbinafine; and (D) $\mathrm{Bi}_{2} \mathrm{O}_{3} \mathrm{NPs}$.

Note: The bar indicates I $\mu \mathrm{m}$.

Abbreviations: $\mathrm{Bi}_{2} \mathrm{O}_{3}$, bismuth oxide; NP, nanoparticle.

showed that $\mathrm{Bi}_{2} \mathrm{O}_{3}$ NPs did not promote cytotoxic effects in the Vero cells at 24 hours of exposure compared with the cells without NP. The nuclei and, indeed, all the cells looked very similar in the presence or absence of $\mathrm{Bi}_{2} \mathrm{O}_{3}$ NPs (Figure 5). These results suggest the absence of cytotoxicity by $\mathrm{Bi}_{2} \mathrm{O}_{3}$ NPs, under our experimental conditions.

\section{Discussion}

In this study, we presented evidence of the antimycotic activity of $\mathrm{Bi}_{2} \mathrm{O}_{3} \mathrm{NPs}$. Their efficacy in inhibiting C. albicans growth was significantly better than that of chlorhexidine, nystatin, and terbinafine. These results indicate that $\mathrm{Bi}_{2} \mathrm{O}_{3}$ NPs are better antifungal agents than the most commonly used oral antiseptic and commercial antifungal agents. To be assured that the antifungal effect was due to the nanostructured $\mathrm{Bi}_{2} \mathrm{O}_{3}$, this was compared with the antifungal effect of bulk $\mathrm{Bi}_{2} \mathrm{O}_{3}$. The $\mathrm{Bi}_{2} \mathrm{O}_{3}$ NPs were two times more effective than the polycrystalline $\mathrm{Bi}_{2} \mathrm{O}_{3}$ in inhibiting fungal growth. This result was very important because it demonstrated the effectiveness of the nanostructured material versus the same bulk compound. Bismuth salicylate, a typical molecular bismuth derivative, has been employed to treat fungal infections but was not shown to inhibit the fungal growth, ${ }^{23}$ suggesting that it is the nanostructured particle of $\mathrm{Bi}_{2} \mathrm{O}_{3}$ that is conferred with the antimicrobial properties described earlier. ${ }^{15}$ These results suggest that $\mathrm{Bi}_{2} \mathrm{O}_{3}$ NPs could be very interesting antifungal agents. Previously, it was reported that zinc, titanium, and silver NPs have very good antifungal activity; ${ }^{24-26}$ however, it is not possible to establish any quantitative antibiofilm activity comparison, due to the type of published results.

Inorganic nanostructures have many applications in fields like the biological sciences and medicine. NPs have been applied as coating materials and in treatments and diagnosis. ${ }^{27}$ NPs of titanium dioxide, silver, diamonds, iron oxides, carbon nanotubes, and biodegradable polymers have all been studied for their use in diagnosis and treatments. NPs of silver, copper oxides, and selenium have been reported to have antimicrobial activity. ${ }^{28-30}$ The advantages of inorganic NPs are their high surface-to-volume ratios, different shapes, many structural defects, (the presence of irregularities in the crystal lattice of the nanostructured bismuth oxide) and of course, their nanoscale size, which allows more active sites to interact with biological systems such as bacteria, fungi, and viruses. This is the most important difference between NPs and the typical organic molecular antimicrobial agents, and could minimize the risk of developing antimicrobial resistance.

The mechanism of the antimicrobial activity of inorganic NPs is not completely understood, and their precise mechanism of action against bacteria and fungi remains to be fully eluci-
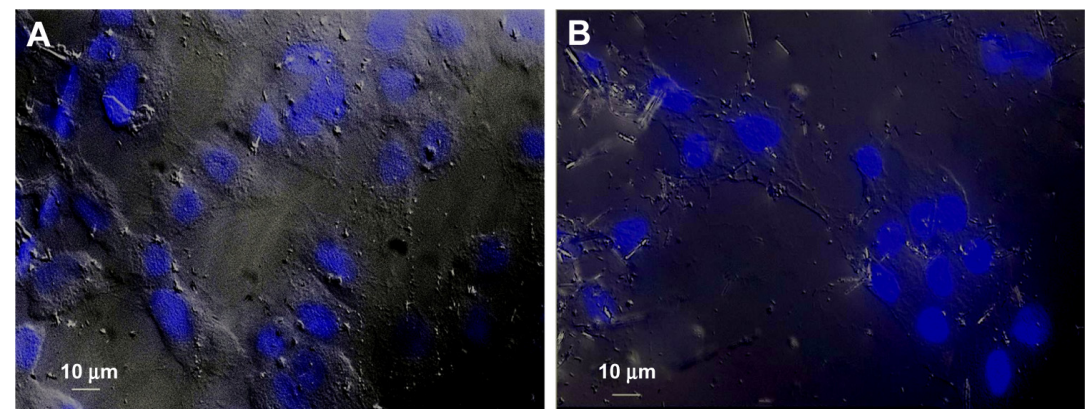

Figure 5 Cytotoxicity of bismuth oxide nanoparticles detected by fluorescence microscopy. The possible cytotoxic effect of bismuth oxide nanoparticles was evaluated in monkey kidney cells by staining the nuclei with DAPI and visualizing cell morphology with DIC. As positive control, Vero cells were used. (A) Positive control and (B) Vero cells, after interacting with bismuth oxide nanoparticles, for 24 hours.

Abbreviations: DAPI, 4',6-diamidino-2-phenylindole; DIC, differential interference contrast microscopy. 
dated. It has been shown that positive charges on the metal ion are critical for the antimicrobial activity, allowing for the electrostatic attraction between a negatively charged cell membrane and the positively charged NPs. ${ }^{31}$ It has also been reported that silver NPs can damage DNA, alter gene expression, and affect the membrane-bound respiratory enzymes. ${ }^{32-34}$

As previously mentioned, $\mathrm{Bi}_{2} \mathrm{O}_{3}$ has a marked basic character, and when this compound is suspended in water, it tends to be associated with hydroxyl ions and water molecules on its surface, similar to titanium dioxide, zinc oxide, tin dioxide, and other metal oxides. ${ }^{35-39}$ When $\mathrm{Bi}_{2} \mathrm{O}_{3}$ is nanostructured, its ionic character is enhanced compared with the same bulk material, ie, it becomes a "harder" species with respect to its electrons (according to Pearson's theory of hard and soft acids and bases). ${ }^{40}$ As a consequence, when $\mathrm{Bi}_{2} \mathrm{O}_{3}$ is nanostructured, its dissociating character increases, as does the overall surface of the material. Therefore, the amount of $\mathrm{OH}^{-1}$ ions and water molecules bound to the surfaces of the nanocrystallites is higher than in the same bulk material, as is sketched in (Figure 1D). Thus, $\mathrm{Bi}_{2} \mathrm{O}_{3}$ NPs dispersed in water are a chemical species with a highly negative surface electric potential; subsequently, these nanostructured species are strongly basic aggregation points, conferring them with a lethal character for the immersed $C$. albicans fungi. It has been reported that several microorganisms are very sensitive to alkaline media, among them, C. albicans. ${ }^{41}$ We suggest that this is the basis for the fungicidal character of $\mathrm{Bi}_{2} \mathrm{O}_{3}$ nanoclusters. Additionally, we cannot discard antifungal activity mechanisms involving free radicals, due to the presence of $\mathrm{CO}_{2}$ in the culture media ${ }^{42}$ and the inherent $\alpha-\mathrm{Bi}_{2} \mathrm{O}_{3} \mathrm{NPs}$ photocatalytic properties. ${ }^{43}$ However, more experimental evidences are needed to support these hypotheses.

In parallel to their antifungal activity, the $\mathrm{Bi}_{2} \mathrm{O}_{3} \mathrm{NPs}$ had the potential to interfere with biofilm formation of $C$. albicans. This antibiofilm activity of the $\mathrm{Bi}_{2} \mathrm{O}_{3} \mathrm{NPs}$ was also studied. Surprisingly, the antibiofilm formation effect was complete in the media with the $\mathrm{Bi}_{2} \mathrm{O}_{3}$ NPs. This effect was unexpected since $\mathrm{Bi}_{2} \mathrm{O}_{3}$ NPs only reduced cell growth and did not completely inhibit it. To explain this observation, we suggest that $85 \%$ of cells were inactivated during inoculation with $\mathrm{Bi}_{2} \mathrm{O}_{3}$ NPs and that surviving cells were insufficient to build a biofilm. It may be that they went into planktonic and stress states due the presence of the $\mathrm{Bi}_{2} \mathrm{O}_{3} \mathrm{NPs}$, and it is possible that they were lost during the wash of dye excess. In the presence of chlorhexidine and $\mathrm{Bi}_{2} \mathrm{O}_{3} \mathrm{NPs}$, we only observed (via fluorescence microscopy) cellular debris on a dark background - mainly DNA of dead fungus with accumulates of dye. Morphologically, these dye accumulates clearly differed from fungal biofilm.
It is noteworthy that there are published reports of fungal growth inhibition, including inhibition of C. albicans, where inorganic NPs, such as diamond-, silver-, gold-, platinum-, and palladium-based NPs, were used as antifungal agents. ${ }^{44}$ Particularly, silver (Ag) NPs have also been shown to inhibit yeast growth, ${ }^{31}$ and their antifungal activity against certain species of Candida ${ }^{45}$ is well documented. These studies show evidence for the molecular mechanism of Ag NPs activity, whereby Ag NPs act on and inhibit a number of oxidative enzymes, such as yeast alcohol dehydrogenase, through the generation of reactive oxygen species. ${ }^{31}$ Ag NPs have been demonstrated to exhibit a desirable and promising antifungal effect in several studies, with no serious side effects to the host. ${ }^{46}$ However, the results and the experimental conditions used in the aforementioned studies are not comparable with those of this research.

The possible cytotoxic effect of $\mathrm{Bi}_{2} \mathrm{O}_{3}$ NPs was explored in monkey kidney (Vero) cells by fluorescence microscopy. No change was detected in the morphology of the nuclei or, indeed, of all cells in the presence or absence of $\mathrm{Bi}_{2} \mathrm{O}_{3} \mathrm{NPs}$, suggesting the lack of cytotoxic effect after 24 hours of exposure. Earlier, the toxicity of metal oxide NPs, mainly Ag oxide $\left(\mathrm{Ag}_{2} \mathrm{O}\right)$, zinc oxide $(\mathrm{ZnO})$, and iron oxide $\left(\mathrm{Fe}_{2} \mathrm{O}_{3}\right),{ }^{47}$ was reported. The possible toxicity of $\mathrm{Bi}_{2} \mathrm{O}_{3}$ NPs was analyzed using the same concentration of NPs as was employed in those antifungal assays. The preliminary results of this study reveal no cytotoxicity of colloidal $\mathrm{Bi}_{2} \mathrm{O}_{3} \mathrm{NPs}$, at least under the experimental conditions previously described. This lack of cytotoxicity can be attributed to the very small amount of inorganic nanomaterial that interacted with the Vero cells. The total $\mathrm{Bi}_{2} \mathrm{O}_{3}$ nanocluster mass and doses of $0.15 \mu \mathrm{g} / \mathrm{mL}$ introduced were not enough to cause cell damage.

For particle toxicity, three factors are crucial: size, shape, and chemical composition. A reduction in the size of a nanosized particle results in an increase in the specific surface area of the nanostructured powder. Therefore more chemical species may attach to its surface, which enhances its reactivity and results in an increase in its toxic effects. ${ }^{48,49}$

In this case, the colloidal $\mathrm{Bi}_{2} \mathrm{O}_{3} \mathrm{NPs}$ had a relatively small size; however, the number of nanoclusters introduced into the Vero cell culture medium, was significantly low compared with the total loads of the other two derivatives of bismuth $\left(\mathrm{Bi}_{2} \mathrm{O}_{3}\right.$ in bulk form and bismuth nitrate).

In this work we focused on the effectiveness of $\mathrm{Bi}_{2} \mathrm{O}_{3}$ NPs in inhibiting the growth of $C$. albicans. All together, the experimental data suggest that $\mathrm{Bi}_{2} \mathrm{O}_{3}$ NPs could be an interesting alternative to combat the fungal infections at the origin of biofilms. The property of $\mathrm{Bi}_{2} \mathrm{O}_{3} \mathrm{NPs}$ could be used in 
oral health, supporting the antifungal activity of oral antiseptics. Further experiments will be necessary to determine the possible toxicity of $\mathrm{Bi}_{2} \mathrm{O}_{3} \mathrm{NPs}$ and analyze the genotoxicity (apoptosis, DNA fragmentation, DNA damage) in human fibroblasts cultures and analyze their potential use in humans.

In conclusion, $\mathrm{Bi}_{2} \mathrm{O}_{3} \mathrm{NPs}$ of $77 \mathrm{~nm}$ average size have an antimycotic activity inhibiting the growth of $C$. albicans, as well as an antibiofilm activity. This behavior is different from the one of the corresponding bulk material; so, the observed activity is a size-dependent property, an explanation that was proposed first time. Additionally, our results suggest that the $\mathrm{Bi}_{2} \mathrm{O}_{3} \mathrm{NPs}$, under the experimental tested conditions and concentrations, do not exhibit cytotoxicity.

\section{Acknowledgments}

The authors wish to thank Vilma Suarez-Martinez and Myriam De la Garza-Ramos, from FO UANL, for support in growing the C. albicans, and Ernesto Torres, from FM UANL, for providing the Vero cell line. Donaji VelascoArias and Rene Hernandez-Delgadillo thank CONACyT for the Ph D scholarships. Claudio Cabral-Romero wishes to thank the Research Department-UANL for financial support (Paicyt CN-775-11) and CONACyT for financing the project (No 183825). Also, David Diaz wants to express his gratitude to DGAPA-UNAM and CONACyT, for their financial support (projects PAPIIT IN 101009 and SEP-CB132094, respectively). Finally, Inti Zumeta-Dubé is grateful for the postdoctoral fellowship award from UE-CONACyT, BisNano project.

\section{Disclosure}

The authors report no conflicts of interest in this work.

\section{References}

1. Costerton JW. Overview of microbial biofilms. J Ind Microbiol. 1995; 15(3):137-140.

2. Chandra J, Kuhn DM, Mukherjee PK, Hoyer LL, McCormick T, Ghannoum MA. Biofilm formation by the fungal pathogen Candida albicans: development, architecture, and drug resistance. J Bacteriol. 2001;183(18):5385-5394.

3. Reyes A, Reyes AC. Studies on Candida albicans infection in Filipino children. II. Prevalence of oral moniliasis. Acta Med Philipp. 1956-1957;13(1-4):151-155.

4. Fortún J. Antifungal therapy update: new drugs and medical uses. Enferm Infecc Microbiol Clin. 2011;29 Suppl 5:38-44. Spanish.

5. Falagas ME, Fragoulis KN, Karydis I. A comparative study on the cost of new antibiotics and drugs of other therapeutic categories. PloS One. 2006;1:e11.

6. Marchaim D, Lemanek L, Bheemreddy S, Kaye KS, Sobel JD. Fluconazole-resistant Candida albicans vulvovaginitis. Obstet Gynecol. 2012;120(6):1407-1414.

7. Sasse C, Dunkel N, Schäfer T, et al. The stepwise acquisition of fluconazole resistance mutations causes a gradual loss of fitness in Candida albicans. Mol Microbiol. 2012;86(3):539-556.
8. Kirk RE, Othmer DF. Encyclopedia of Chemical Technology, 5th ed. Hoboken: John Wiley and Sons Inc; 2004.

9. Figueroa-Quintanilla D, Salazar-Lindo E, Sack RB, et al. A controlled trial of bismuth subsalicylate in infants with acute watery diarrheal disease. New Engl J Med. 1993;328(23):1653-1658.

10. Mehring M. From molecules to bismuth oxide-based materials: Potential homo- and heterometallic precursors and model compounds. Coord Chem Rev. 2007;251(7-8):974-1006.

11. Cox PA. The Elements: Their Origin, Abundance, and Distribution. Oxford: Oxford University Press; 1989.

12. Earnshaw A, Greenwood N. Chemistry of the Elements, 1st ed. Pergmon Press Ltd. Oxford England; 1984.

13. Adamian ZN, Abovian HV, Aroutiounian VM. Smoke sensor on the base of $\mathrm{Bi}_{2} \mathrm{O}_{3}$ sesquioxide. Sens Actuators B Chem. 1996;35(1-3):241-243.

14. Leontie L, Caraman M, Alexe M, Harnagea C. Structural and optical characteristics of bismuth oxide thin films. Surface Science. 2002; 507-510:480-485.

15. Hernandez-Delgadillo R, Velasco-Arias D, Diaz D, et al. Zerovalent bismuth nanoparticles inhibit Streptococcus mutans growth and formation of biofilm. Int J Nanomedicine. 2012;7:2109-2113.

16. Mosmann T. Rapid colorimetric assay for cellular growth and survival: application to proliferation and cytotoxicity assays. J Immunol Methods. 1983;65(1-2):55-63.

17. Liu Y, Peterson DA, Kimura H, Schubert D. Mechanism of cellular 3-(4,5-dimethylthiazol-2-yl)-2,5-diphenyltetrazolium bromide (MTT) reduction. J Neurochem. 1997;69(2):581-593.

18. Andrews JM. Determination of minimum inhibitory concentrations. J Antimicrob Chemother. 2001;48 Suppl 1:5-16.

19. Yue H, Eastman PS, Wang BB, et al. An evaluation of the performance of cDNA microarrays for detecting changes in global mRNA expression. Nucleic Acids Res. 2001;29(8):E41-E41.

20. Frey T. Nucleic acid dyes for detection of apoptosis in live cells. Cytometry. 1995;21(3):265-274.

21. Perera VS, Hao J, Gao M, et al. Nanoparticles of the novel coordination polymer $\mathrm{KBi}(\mathrm{H} 2 \mathrm{O}) 2[\mathrm{Fe}(\mathrm{CN}) 6] \cdot \mathrm{H} 2 \mathrm{O}$ as a potential contrast agent for computed tomography. Inorg Chem. 2011;50(17):7910-7912.

22. Kubista M, Akerman B, Nordén B. Characterization of interaction between DNA and 4',6-diamidino-2-phenylindole by optical spectroscopy. Biochemistry. 1987;26(14):4545-4553.

23. Alharbi SA, Mashat BH, Al-Harbi NA, Wainwright M, Aloufi AS, Alnaimat S. Bismuth-inhibitory effects on bacteria and stimulation of fungal growth in vitro. Saudi J Biol Sci. 2012;19(2):147-150.

24. Lipovsky A, Nitzan Y, Gedanken A, Lubart R. Antifungal activity of $\mathrm{ZnO}$ nanoparticles - the role of ROS mediated cell injury. Nanotechnology. 2011;22(10):105101.

25. Tatlıdil İ, Sökmen M, Breen C, Clegg F, Buruk CK, Bacaksız E. Degradation of Candida albicans on $\mathrm{TiO} 2$ and $\mathrm{Ag}-\mathrm{TiO} 2$ thin films prepared by sol-gel and nanosuspensions. Journal of Sol-Gel Science Technology. 2011;60(1):23-32.

26. Hwang IS, Lee J, Hwang JH, Kim KJ, Lee DG. Silver nanoparticles induce apoptotic cell death in Candida albicans through the increase of hydroxyl radicals. FEBS J. 2012;279(7):1327-1338.

27. Colvin VL. The potential environmental impact of engineered nanomaterials. Nat Biotechnol. 2003;21(10):1166-1170.

28. Sondi I, Salopek-Sondi B. Silver nanoparticles as antimicrobial agent: a case study on E. coli as a model for Gram-negative bacteria. J Colloid Interface Sci. 2004;275(1):177-182.

29. Ren G, Hu D, Cheng EW, Vargas-Reus MA, Reip P, Allaker RP. Characterisation of copper oxide nanoparticles for antimicrobial applications. Int J Antimicrob Agents. 2009;33(6):587-590.

30. Tran PA, Webster TJ. Selenium nanoparticles inhibit Staphylococcus aureus growth. Int J Nanomedicine. 2011;6:1553-1558.

31. Kim JS, Kuk E, Yu KN, et al. Antimicrobial effects of silver nanoparticles. Nanomedicine. 2007;3(1):95-101.

32. Feng QL, Wu J, Chen GQ, Cui FZ, Kim TN, Kim JO. A mechanistic study of the antibacterial effect of silver ions on Escherichia coli and Staphylococcus aureus. J Biomed Mater Res. 2000;52(4):662-668. 
33. Yamanaka M, Hara K, Kudo J. Bactericidal actions of a silver ion solution on Escherichia coli, studied by energy-filtering transmission electron microscopy and proteomic analysis. Appl Environ Microbiol. 2005;71(11):7589-7593.

34. Bragg PD, Rainnie DJ. The effect of silver ions on the respiratory chain of Escherichia coli. Can J Microbiol. 1974;20(6):883-889.

35. Xu JJ, Chen MD, Fu DG. Preparation of bismuth oxide/titania composite particles and their photocatalytic activity to degradation of 4-chlorophenol. Transactions of Nonferrous Metals Society of China. 2011;21(2):340-345.

36. Lindan PJD. Water chemistry at the $\mathrm{SnO}_{2}(110)$ surface: the role of inter-molecular interactions and surface geometry. Chem Phys Lett. 2000;328(4-6):325-329.

37. Batzill M, Bergermayer W, Tanaka I, Diebold U. Tuning the chemical functionality of a gas sensitive material: Water adsorption on $\mathrm{SnO}_{2}(101)$. Surf Sci. 2006;600(4):L29-L32.

38. Duncan DA, Allegretti F, Woodruff DP. Water does partially dissociate on the perfect $\mathrm{TiO}_{2}$ (110) surface: A quantitative structure determination. Phys Rev B. 2012;86(4):045411.

39. Noei H, Qiu H, Wang Y, Löffler E, Wöll C, Muhler M. The identification of hydroxyl groups on $\mathrm{ZnO}$ nanoparticles by infrared spectroscopy. Phys Chem Chem Phys. 2008;10(47):7092-7097.

40. Pearson RG. Chemical hardness and density functional theory. J Chem Sci. 2005;117(5):369-377.

41. Guerreiro-Tanomaru JM, Cornélio AL, Andolfatto C, Salles LP, Tanomaru-Filho M. pH and antimicrobial activity of Portland cement associated with different radiopacifying agents. ISRN Dent. 2012;2012: 469019.
42. Medinas DB, Cerchiaro G, Trindade DF, Augusto O. The carbonate radical and related oxidants derived from bicarbonate buffer. IUBMB Life. 2007;59(4-5):255-262.

43. Muruganandham M, Amutha R, Lee GJ, Hsieh SH, Wu JJ, Sillanpää M. Facile fabrication of tunable $\mathrm{Bi}_{2} \mathrm{O}_{3}$ self-assembly and its visible light photocatalytic activity. J Phys Chem C. 2012;116(23):12906-12915.

44. Chwalibog A, Sawosz E, Hotowy A, et al. Visualization of interaction between inorganic nanoparticles and bacteria or fungi. Int $J$ Nanomedicine. 2010;5:1085-1094.

45. Kim KJ, Sung WS, Moon SK, Choi JS, Kim JG, Lee DG. Antifungal effect of silver nanoparticles on dermatophytes. J Microbiol Biotechnol. 2008;18(8):1482-1484.

46. Sardi JC, Scorzoni L, Bernardi T, Fusco-Almeida AM, Mendes Giannini MJ. Candida species: current epidemiology, pathogenicity, biofilm formation, natural antifungal products and new therapeutic options. J Med Microbiol. 2013;62(Pt 1):10-24.

47. Kumar V, Kumari A, Guleria P, Yadav SK. Evaluating the toxicity of selected types of nanochemicals. Rev Environ Contam Toxicol. 2012;215:39-121.

48. Linkov I, Satterstrom FK, Corey LM. Nanotoxicology and nanomedicine: making hard decisions. Nanomedicine. 2008;4(2):167-171.

49. Suh WH, Suslick KS, Stucky GD, Suh YH. Nanotechnology, nanotoxicology, and neuroscience. Prog Neurobiol. 2009;87(3): $133-170$.

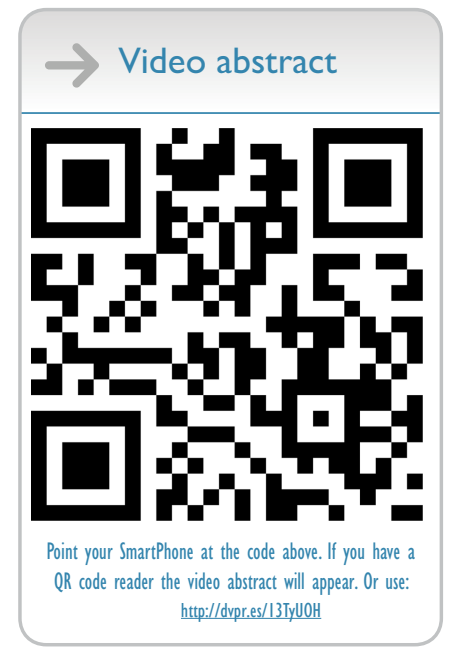

International Journal of Nanomedicine

\section{Publish your work in this journal}

The International Journal of Nanomedicine is an international, peerreviewed journal focusing on the application of nanotechnology in diagnostics, therapeutics, and drug delivery systems throughout the biomedical field. This journal is indexed on PubMed Central, MedLine, CAS, SciSearch ${ }^{\circledR}$, Current Contents ${ }^{\circledR} /$ Clinical Medicine,

\section{Dovepress}

Journal Citation Reports/Science Edition, EMBase, Scopus and the Elsevier Bibliographic databases. The manuscript management system is completely online and includes a very quick and fair peer-review system, which is all easy to use. Visit http://www.dovepress.com/ testimonials.php to read real quotes from published authors. 